TECHNICAL TRANSACTIONS 8/2018

CHEMISTRY

DOI: $10.4467 / 2353737$ XCT.18.115.8890 SUBMISSION OF THE FINAL VERSION: 16/07/2018

\author{
Łukasz Majewski (D) orcid.org/0000-0002-9766-2064 \\ l.majewski@pollub.pl \\ Janusz W. Sikora (iD orcid.org/0000-0002-2790-8823 \\ Department of Technology and Polymer Processing, Mechanical Engineering Faculty, \\ Lublin University of Technology
}

\title{
MECHANICAL PROPERTIES OF POLYETHYLENE \\ FILLED WITH TREATED NEUBURG SILICEOUS EARTH
}

WŁAŚCIWOŚCI MECHANICZNE POLIETYLENU

NAPEŁNIONEGO MODYFIKOWANĄ NEUBURSKĄ GLINKĄ KRZEMIANOWĄ

\begin{abstract}
This paper reports the results of research on the mechanical properties of HDPE-matrix composite filled with three types of Neuburg Siliceous Earth (NSE). The HDPE/NSE composites are prepared by twinscrew direct extrusion, with the filler content ranging between $0 \mathrm{wt} \%$ and $60 \mathrm{wt} \%$. Thereby, the prepared molded pieces are subjected to tests in order to determine Young's modulus and tensile strength, impact strength and hardness. The results are thoroughly examined based on the morphological and geometrical features of the applied fillers, such as particle size $(2-10 \mu \mathrm{m})$ and specific surface $(7-9 \mathrm{~m} 2 / \mathrm{g})$. The effect of the chemical properties of the filler surface on its interaction with the matrix and strength is determined. The effects of the chemical activation of the filler surface by vinyl-functional silanes on their strength properties is described, and the variations in interactions on the matrix-filler interface are explained.
\end{abstract}

Keywords: mineral filler, polyolefins, coupling agent, high density polyethylene, HDPE

\section{Streszczenie}

W poniższej pracy przedstawiono wyniki badań właściwości mechanicznych kompozytów na osnowie HDPE napełnionych trzema różnymi rodzajami modyfikowanej Neuburskiej Glinki Krzemianowej. Kompozyty HDPE/NGK przygotowano w procesie dwuślimakowego wytlaczania współbieżnego zmieniając zawartość napełniacza w przedziale 0-60\% mas. Gotowe wypraski wtryskowe poddano próbie zrywania, w celu wyznaczenia m.in. modułu Younga i wytrzymałości na rozciąganie oraz badaniom udarności i twardości. Dokonano szczegółowej analizy otrzymanych wyników w oparciu o cechy morfologiczne i geometryczne napełniaczy, takie jak wielkość ziarna $(2-10 \mu \mathrm{m})$ i powierzchnia właściwa (7-9 m2/g). Określono wplyw chemicznych właściwości powierzchni napełniacza na jego interakcje z osnową i właściwości wytrzymałościowe. Opisano efekty chemicznej aktywacji powierzchni napełniaczy środkami sprzęgającymi w postaci winylo-funkcyjnych silanów na właściwości wytrzymałościowe oraz wyjaśniono, w jaki sposób zmieniają oddziaływania na granicy fazowej osnowa-napełniacz.

Słowa kluczowe: napełniacz mineralny, poliolefiny, środek sprzęgający, polietylen dużej gęstości, PE-HD 


\section{Introduction}

Injection molding is currently the most popular polymer processing method, mainly because of its short duration, a wide range of operational opportunities it offers, and high precision of produced molded pieces regardless of the material used. This process is employed to manufacture a vast majority of complex-shaped parts, which must meet high dimensional accuracy requirements [1]. Currently, about a third of thermoplastics used in the polymer processing industry are subjected to injection molding, and a half of manufactured machines and devices are used for injection molding [1]. The application of untreated polymers does not, however, meet today's design and economic requirements. Given the emphasis on reducing production costs along with a growing demand for materials with specified new properties, polymers are more and more often subjected to modification $[2,3]$. Polymers with varying properties are produced by physical or chemical modification, reactive processing, the addition of fillers or auxiliary agents $[2,4-6]$. For this reason, the composite injection molding process is preceded by extrusion to produce extrudate made of primary polymers and composite granulated products, which are then used to manufacture composite molded pieces [7].

The making of polymer compounds is an interdisciplinary problem. When selecting a filler and its content, one must take into account various factors and parameters from the field of chemistry, physical chemistry of polymers, mechanical engineering, rheology, materials engineering, and even the design of processing machines $[2,3,8]$. The selection of a suitable filler and its content enables shaping properties of composite materials as desired. Polymer compounds are usually used in order to improve properties, such as impact strength, hardness, grindability, tensile or bending strength, chemical resistance, temperature stability, flammability, thermal and electrical conductivity, etc. [2-4, 9]. Besides the filler's type and content, the properties of produced composites are also significantly affected by the degree of polymer dispersion together with the polymer's structure, characteristics of adhesion phenomena, the applied processing technology, etc. [4, 10, 11]. It is a more and more common practice to modify filler surface in order to intensify surface interactions by increasing the specific surface area of the particles or by coating the particles with an active compound to increase interfacial compatibility $[2,3,5]$. This leads to higher cohesion and uniformity of the composite $[4,9,12]$.

The objective of this study is to describe the variations in selected mechanical properties of a high-density polyethylene-matrix composite versus the content of treated Neuburg Siliceous Earth (NSE), and to explain the effect of NSE modifications on the observed variations in the examined properties of the produced composite. Another goal of this paper is also to determine the suitability of NSE for thermoplastics processing applications, a problem which has not yet received adequate attention. 


\section{Experimental}

\subsection{Material}

The tests were conducted using high-density polyethylene, Hostalen GD 7255, manufactured by Orlen Polyolefines (Plock, Poland) and mainly used for the production of details and thin-walled parts. Basic properties of the tested polymer provided by the manufacturer are listed in Table 1.

Table 1. Basic properties of high-density polyethylene Hostalen GD 7255

\begin{tabular}{|c|c|c|}
\hline Property & Unit & Value \\
\hline Density & $\mathrm{kg} / \mathrm{m}^{3}$ & 955 \\
\hline Melt flow rate $\left(190^{\circ} \mathrm{C} / 2.16 \mathrm{~kg}\right)$ & $\mathrm{g} / 10 \mathrm{~min}$ & 4 \\
\hline Melt flow rate $\left(190^{\circ} \mathrm{C} / 5.0 \mathrm{~kg}\right)$ & $\mathrm{g} / 10 \mathrm{~min}$ & 11 \\
\hline Tensile modulus & $\mathrm{MPa}$ & 1180 \\
\hline Tensile Stress at Yield & $\mathrm{MPa}$ & 27 \\
\hline Tensile Strain at Yield & $\%$ & 8 \\
\hline Charpy notched impact strength $\left(23^{\circ} \mathrm{C}\right.$, Type 1, Notch $\left.\mathrm{A}\right)$ & $\mathrm{kJ} / \mathrm{m}^{2}$ & 10 \\
\hline Charpy notched impact strength $\left(-30^{\circ} \mathrm{C}\right.$, Type 1, Notch $\left.\mathrm{A}\right)$ & $\mathrm{kJ} / \mathrm{m}^{2}$ & 5 \\
\hline Shore hardness $($ Shore $\mathrm{D})$ & ${ }^{\circ} \mathrm{ShD}$ & 60 \\
\hline Ball indentation hardness $(\mathrm{H} 132 / 30)$ & $\mathrm{MPa}$ & 52 \\
\hline Vicat softening temperature $\left(\mathrm{B} 50,50^{\circ} / \mathrm{h}, 50 \mathrm{~N}\right)$ & ${ }^{\circ} \mathrm{C}$ & 70 \\
\hline
\end{tabular}

The applied fillers were different types of treated siliceous earth manufactured in the vicinity of Neuburg, Germany. Neuburg siliceous earth is a natural mixture of silica and lamellar kaolinite impossible to separate by physical methods. The two minerals form a loose structure the silica has the form of aggregated spherical cryptocrystalline particles covered by its amorphous variety due to natural forming processes. Given such a structure, the silica has an extensive specific surface, which has a positive effect on its mechanical properties $[13,14]$.

Currently, there are two groups of fillers containing Neuburg Siliceous Erath manufactured by Hoffman Mineral (Neuburg, Germany). The first group includes natural siliceous earth, Silitin, the types of which differ with respect to particle size distribution and color neutrality. The other group includes siliceous earth treated with silanes; these fillers have varying properties.

Table 2 lists a selection of properties describing the three NSE types examined in this study. 
Table 2. Selected properties of treated types of NSE [15]

\begin{tabular}{|c|c|c|c|c|}
\hline Property & Unit & Silfit Z91 & Aktifit VM & Aktisil VM56 \\
\hline Base material & - & Sillitin Z86 & Silfit Z91 & Sillitin Z86 \\
\hline Particle size & $\mu \mathrm{m}$ & $2-10$ & $2-10$ & $2.2-10$ \\
\hline Density & $\mathrm{kg} / \mathrm{m}^{3}$ & 2600 & 2600 & 2600 \\
\hline Bulk density & $\mathrm{kg} / \mathrm{m}^{3}$ & 330 & 420 & 320 \\
\hline Specific surface area & $\mathrm{m}^{2} / \mathrm{g}$ & 8 & 7 & 9 \\
\hline Oil absorption & $\mathrm{g} / 100 \mathrm{~g}$ & 55 & 55 & 45 \\
\hline & & Thermal & Addition of & Addition of vinyl- \\
Treatment & - & treatment & vinyl-functional & functional silane \\
& & - calcination & silane & 60 \\
Mineral composition: & & & & 10 \\
Cryptocrystalline silica & & 60 & 60 & 25 \\
Amorphous silica & $\%$ & 0 & 0 & 0 \\
Kaolinite & & 0 & 0 & 5 \\
Calcinated kaolinite & & 30 & 10 & \\
Other & & \multicolumn{3}{c}{} \\
\hline
\end{tabular}

Silfit Z91 is a natural mixture of amorphous and cryptocrystalline silica and lamellar kaolinite subjected to calcination $[13,15]$, hence it can be used as a functional filler [13]. The fillers Aktifit VM and Aktisil VM56 were treated by the addition of vinyl-functional silane, an adhesion promoter used for the modification of the surface of mineral materials joined with polyolefines $[4,13,15]$.

\subsection{Test stand}

The preparation of test specimens and determination of their mechanical properties were made possible using the equipment available at the Institut für Produktionstechnik which is part of Westsächsiche Hochschule in Zwickau, Germany. The composite granulate was prepared using a ZSK18 MEGAlab twin-screw direct extruder manufactured by Coperion Werner and Pfleiderer GmbH (Stuttgart, Germany). At its end, the extrusion line had an SP 30 Pure pelletizer from Pell-Tec GmbH (Stuttgart, Germany), used for pelletizing cooled plastic strands. Composite specimens were produced using a Krauss Maffei KM 50-55 CX injection molding machine (Munich, Germany). The tensile testing of the obtained molded pieces was performed using a Z010 Zwick/Roell testing machine (Ulm, Germany). Hardness measurements were made with a Shore hardness tester from Heinrich Bareiss Prüfgerätebau $\mathrm{GmbH}$ (Oberdischingen, Germany). Impact strength measurements were made using a QC-639 F impact tester manufactured by Cometech (Taizhong, Taiwan).

\subsection{Investigated parameters}

Given the objective of the study, we devised a set of key parameters describing the two investigated processes, i.e. extrusion with pelletizing and injection molding, as well as individual test stands. The parameters were divided into five groups. 


\section{Direct factors:}

- molded piece width a, mm,

- molded piece thickness b, mm.

Indirect factors:

- the cross-sectional area of the molded piece $\mathrm{s}, \mathrm{mm}^{2}$,

- the energy required to break the test piece L, kJ,

- Young's modulus E, MPa,

- tensile strength $\sigma \mathrm{m}, \mathrm{MPa}$,

- strain at maximum tensile stress, \%,

- tensile strain at break A, \%,

- tensile stress at break ou, $\mathrm{MPa}$,

- Shore hardness $\mathrm{H},{ }^{\circ} \mathrm{ShD}$,

- impact strength $\mathrm{U}, \mathrm{kJ} / \mathrm{m}^{2}$.

Variables:

- filler type (Silfit Z91, Aktifit VM, Aktisil VM56),

- filler content (10 wt\%, 20 wt\%, $30 w t \%, 40 w t \%, 50 w t \%, 60 w t \%)$.

Constant parameters:

- polymer (HDPE),

- geometrical dimensions of the extruder head nozzle and injection mold cavity,

- the pressure in the extruder head 8 bar,

- technological parameters of the extrusion process: screw rotational speed in the plasticizing unit: $120 \mathrm{rev} / \mathrm{min}$, the temperature in individual zones of the plasticizing unit: $130^{\circ} \mathrm{C}, 140^{\circ} \mathrm{C}, 150^{\circ} \mathrm{C}, 160^{\circ} \mathrm{C}, 170^{\circ} \mathrm{C}$ and $180^{\circ} \mathrm{C}$,

- the temperature of the injection mold: $19^{\circ} \mathrm{C}$,

- technological parameters of the injection molding process: temperature in the plasticizing unit - 180,200 and $220^{\circ} \mathrm{C}$, injection pressure - $1050 \mathrm{bar}$, holding pressure -600 bar, holding time $-6 \mathrm{~s}$, cooling time $-20 \mathrm{~s}$, injection cycle time $-35 \mathrm{~s}$.

- Charpy pendulum machine energy $-5 \mathrm{~J}$.

Disturbing factors:

- electric voltage: from $219 \mathrm{~V}$ to $241 \mathrm{~V}$,

- relative air humidity: from $55 \%$ to $65 \%$,

- ambient temperature: from $20^{\circ} \mathrm{C}$ to $24^{\circ} \mathrm{C}$.

The above disturbing factors had a negligible effect on the obtained measurement results.

\subsection{Experimental details}

For the experiments, we prepared three batches of injection molded pieces filled with three types of treated Neuburg Siliceous Earth. The polymer granulate was coated with a surface modifying agent, i.e. carbofunctional silane with the trade name aminopropylotriethoxysilane, and then mechanically mixed with the filler. The modifying agent was $0.4 \mathrm{wt} \%$ of the prepared polymeric compound. The composite granulate was prepared by twin-screw direct extrusion with cold pelletizing. The granulates containing $40 \%-60 \mathrm{wt} \%$ of the filler were prepared by the 
mechanical mixing of the composite granulate with $30 \mathrm{wt} \%$ of NSE containing between $10 \%$ and $30 \%$ of the filler. As a result, we obtained 18 groups of granulated products with different filler types and contents, which were then used to make tensile test pieces. The injection mold cavities had the dimensions complying with ISO 294-1:2002. The tensile tests of composite molded pieces and the determination of their strength parameters were conducted in compliance with ISO 527-1:2012. The Charpy impact tests were run in compliance with ISO 179-1:2010. The Shore hardness measurements were made in compliance with ISO 868:2005.

\section{Results and discussion}

Based on the results, we devised charts illustrating the relationships between Young's modulus, tensile strength, tensile strain at break, strain at maximum tensile stress, tensile strength at break, hardness, as well as the type and content of Neuburg Siliceous Earth. In addition, the results of impact strength tests are discussed.

\subsection{Tensile strength}

The relationship between Young's modulus and the content and type of treated Neuburg Siliceous Earth is illustrated in Fig. 1. The addition of the lowest investigated content of NSE leads to a decrease in Young's modulus of all three types of the filler compared to untreated polyethylene; however, a further increase in the NSE content leads to a gradual increase in Young's modulus for all types of NSE. The decrease in Young's modulus in the entire investigated range for Silfit Z91 is $33 \mathrm{MPa}$, which is $4.6 \%$ of the initial value. Young's modulus of Aktifit VM-filled specimens increases to $844 \mathrm{MPa}$ for $60 \mathrm{wt} \%$ of the filler, which is $117.2 \%$ of the initial value, and for Aktisil VM56 - the parameter is $817 \mathrm{MPa}$ ( $60 \mathrm{wt} \%$ filler), which means an increase by $13.4 \%$.

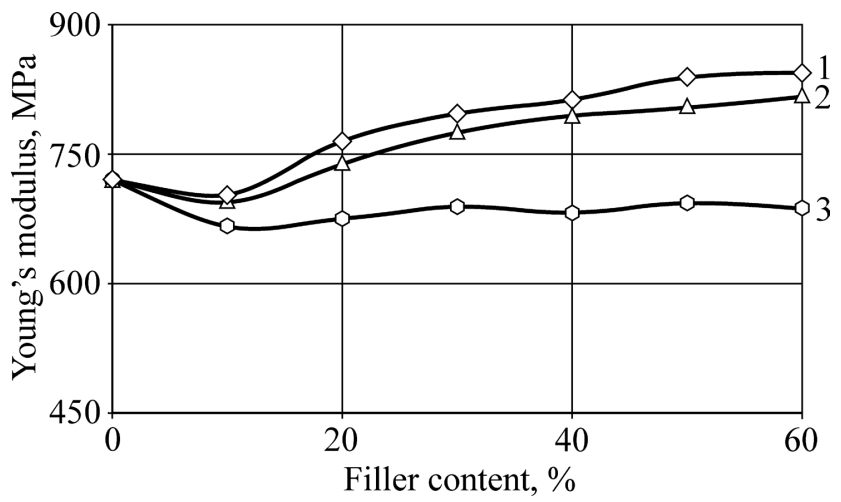

Fig. 1. Young's modulus versus filler content: 1 - Aktifit VM, 2 - Aktisil VM56, 3 - Silfit Z91

Young's modulus describes the elasticity of a given material, and its increase means that rigidity has increased while strain has decreased due to stress. The addition of mineral 
microfillers leads to an increase in rigidity byincreasing the crystallization degree of the polymer matrix in the immediate vicinity of the filler $[4,12,16,17]$. To improve composite rigidity, it is necessary to obtain an adequate degree of dispersion of the filler in the die impression [4]. The coating of Aktisil VM56 and Aktifit VM particle surfaces with a compatibilizer (vinylfunctional silane) to facilitate particles dispersion [18] led to a higher rigidity and Young's modulus. Silfit Z91 was not treated with any coupling agent. It was subjected to calcination, a process which leads to the degradation of surface hydroxyl groups and assigning filler particles with hydrophobic properties $[19,20]$. This operation should improve the dispersion of filler particles in the matrix with hydrophobic polymer chains. Nonetheless, the study [20] reports that calcinated kaolinite bonds steam from the air, and hence spontaneously produces polar hydroxyl groups on the filler surface, thereby providing this surface with hydrophilic properties, which can decrease the dispersion of filler particles in the non-polar matrix due to the incompatibility of the filler surface and the polymer matrix [18]. This is a probable cause of the decrease in Young's modulus.

The results demonstrate that tensile strength changes in a similar way to Young's modulus. Following the addition of the filler, the tensile strength suddenly decreases; then, it begins to gradually increase with increasing the NSE content (Fig. 2). The tensile strength of the investigated composites obtained at $60 \mathrm{wt} \%$ of the filler is lower than the tensile strength of the original polyethylene $(21 \mathrm{MPa})$, and the measured percentage differences are: $0.5 \%$ for Aktifit VM, 1.9\% for Aktisil VM56 and 6.7\% for Silfit Z91.

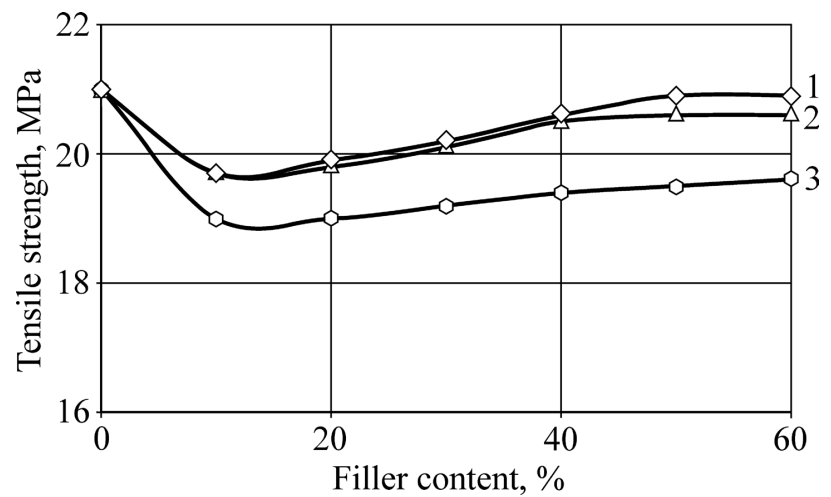

Fig. 2. Tensile strength versus filler content: 1 - Aktifit VM, 2 - Aktisil VM56, 3 - Silfit Z91

The consolidation mechanisms of composites with powder fillers are strictly connected with such properties as particle size, specific surface and the degree of particle dispersion in the matrix, as well as the properties of adhesion promoters which cause the coupling of filler particles and matrix material due to chemical bonds [4]. The observed drop in the tensile strength of the three filler types can result from a wide range of particle sizes (Table 2). The mechanism of consolidating polymers with particles is connected with cavitation and the tension of spaces formed in a direction of the acting force [16, 18]. A detailed description of this mechanism is given by Kim and Michler [21]. It is taken that the promoter effect occurs 
for particle size lower than $5 \mu \mathrm{m}$; otherwise, the formed pockets will be too large, and can hence be the place promoting crack initiation [15]. Composite strength can be reduced even due to a small amount of oversized particles [3, 4]. A large specific surface of particles will not produce the desired consolidation effect without a suitable distribution of particles in the matrix [16]. Despite the larger specific surface of particles, the composite specimens filled with Silfit Z91, reveal a significantly higher decrease in their tensile strength than the specimens filled with Aktifit VM. Besides mechanical adhesion, Silfit Z91 does not reveal the presence of any additional fiber-matrix bonding mechanisms, which - combined with lower dispersion - leads to a higher drop in tensile strength. The smaller specific surface of Aktifit VM, when compared to Silfit Z91, results from the nature of the coupling agent. Vinylfunctional silanes can undergo condensation and form complex compounds on the surface, with two alkoxy groups forming a long chain, while the third one forms a bond with the filler's surface [22]. The particle size prevents them from penetrating all surface irregularities, which results in a reduction of the specific surface [4]. The main promoter effect is therefore based on chemical interactions [12], with the surface modifier acting as an intermediary between the mineral filler and the polymeric matrix due to the alkoxy group and the carbon-carbon double bond in the vinyl group [22]. The same relationships can be observed for composites filled with Aktisil VM56, which means that the coupling agent increases the interactions between the polymeric phase and the filler surface [23]. The observed small differences regarding the silane-treated fillers (with the best results observed for Aktifit VM) can stem from the difference in particle size (Table 2).

Minimal tensile strengths at break are shown in Fig. 3. The increase in the content of Aktifit VM causes a decrease in tensile strength at break in the entire investigated range of its content. The tensile strength at break decrease from 11.5 MPa for untreated PE to 7.79 MPa for $60 \mathrm{wt} \%$ of Aktifit VM, i.e. by $32.3 \%$. The charts illustrating the variations in tensile strengths at break versus filler content for Aktisil VM56 and Silfit Z91 differ from those for Aktifit VM. The tensile strength at break initially decreases, and after reaching a certain critical filler content it begins to increase rapidly.

The curve illustrating the relationship between tensile strength at break and filler content for Aktisil VM56 has two characteristic points: the first point marks the moment when the tensile strength at break suddenly increases and can be observed at $40 \mathrm{wt} \%$ of the filler, while the other point marks the beginning of plateau and can be observed at $50 \mathrm{wt} \%$ of the filler. The measured change in the tensile strength at break is $71.3 \%$, from $11.5 \mathrm{MPa}$ for the unfilled polymer to $19.7 \mathrm{MPa}$ for $60 \mathrm{wt} \%$ of the filler. The minimal tensile strength at break for $40 \mathrm{wt} \%$ filler is $4.98 \mathrm{MPa}$. The curve for Silfit Z91 would probably have the same pattern, but the filler contents applied in accordance with the research program did not enable us to indicate on the diagram the point which marks the beginning of the upper plateau. The tensile strength at break at the maximum filler content is $18.9 \mathrm{MPa}$, which indicates an increase of $64.3 \%$, while the minimal value for the $50 \mathrm{wt} \%$ content would amount to $6.46 \mathrm{MPa}$.

The relationship between the strain at maximum tensile stress and the filler type and content is shown in Fig. 4. Compared to the original HDPE, one can observe that the strain at maximum tensile stress decreases from $9 \%$ to $8.7 \%$ for the test specimens containing Aktisil 


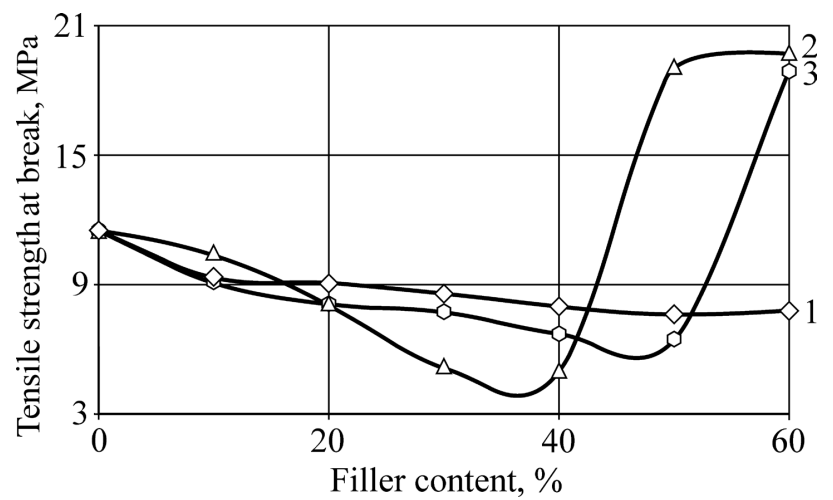

Fig. 3. Tensile strength at break versus filler content: 1 - Aktifit VM, 2 - Aktisil VM56, 3 - Silfit Z91

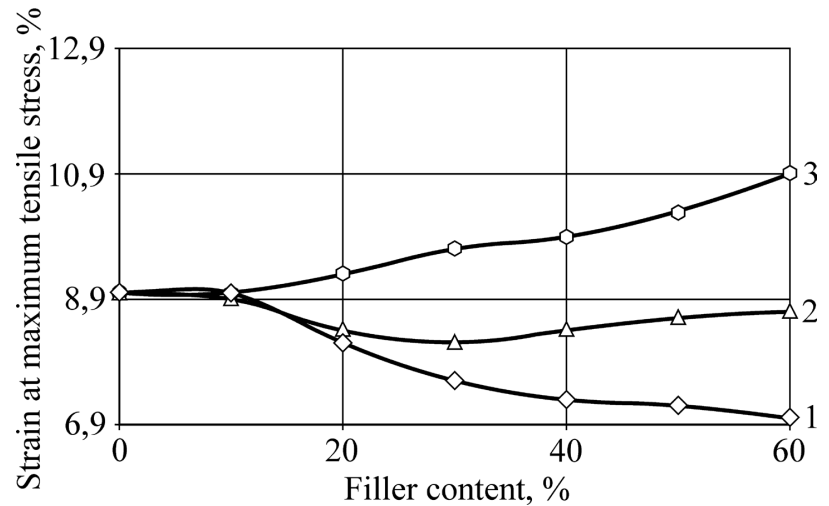

Fig. 4. Strain at maximum tensile stress versus filler content: 1 - Aktifit VM, 2 - Aktisil VM56, 3 - Silfit Z91

VM56. With increasing the content of Aktifit VM in a range from $0 \mathrm{wt} \%$ to $60 \mathrm{wt} \%$, the strain at maximum tensile stress drops to $7 \%$. On increasing the content of Silfit Z91, the strain at maximum tensile stress increases steadily, irrespective of the applied filler content.

The pattern of curve 3 (Fig. 4) probably results from the distribution of filler particles. The filler without a coupling agent can form agglomerates with scarce interactions between the particles [12]. The loose agglomerations of filler particles easily decompose due to tensile stress. As a result, the composite has a lower tensile strength. The study [17] demonstrates that in the composites containing over $5 \mathrm{wt} \%$ of silica, silica tends to form agglomerates and hence its strength decreases, which proves the above considerations. Therefore, an increase in the content of Silfit Z91 leads to a slight yet continuous increase in the tensile strain. The interaction between Aktifit VM and Aktisil VM56 particles and the matrix is much stronger than that observed for Silfit Z91 particles. Modified with silane, the filler surface has acquired organophilic properties, and hence increased its interfacial compatibility enabling their dispersion in the polymeric matrix $[23,24,25]$. The formation of suspended fine particles chemically bonded with the matrix leads to a higher rigidity and lower strain by constraining the movement of polymer chains. The energy of particles dispersion in the matrix decreases with an increase in particle size [4]; therefore, given the presence of aggregated spherical 
silica particles in NSE, the addition of the coupling agent can have a crucial effect on both the filler's dispersion in the matrix and the mechanical properties of the composite.

The diagrams illustrating the relationship between tensile strain at break and filler content and type shown in Fig. 5 reveal a tendency for the tensile strain at the break to decrease with an increase in the content of the three types of NSE. The highest variation in the tensile strain at break in the entire range of the investigated variable is observed for the specimens containing Aktifit VM, where the tensile strain at break decreases from 590\% (PE) to 16\% at the highest filler content. Following the application of Aktisil VM56, the strains in the polyethylene composite decrease to $8.4 \%$, and after the addition of Silfit Z91 - they decrease to $44 \%$ for the same range of the investigated variable.

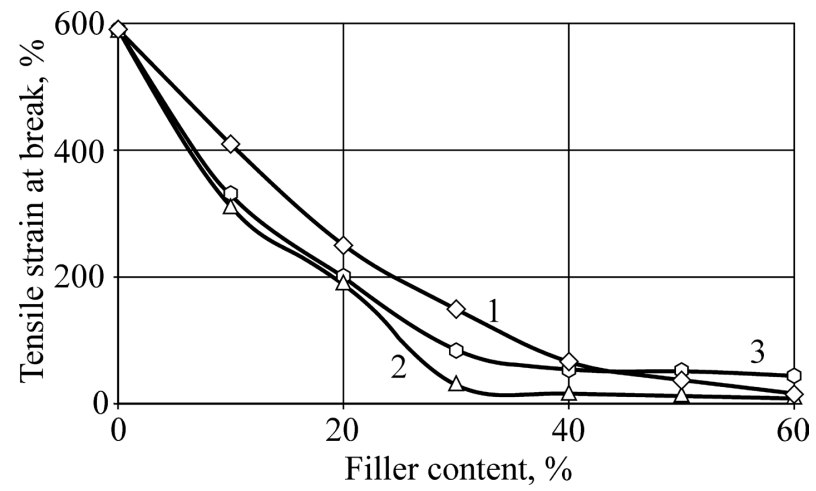

Fig. 5. Tensile strain at break versus filler content: 1 - Aktifit VM, 2 - Aktisil VM56, 3 - Silfit Z91

The addition of high contents of the mineral fillers leads to reduced composite elasticity described by tensile strain at break. Despite the modification of filler surface by vinylfunctional silane, the test specimens containing Aktifit VM exhibit only slightly higher strength properties compared to those filled with Aktisil VM56. This can probably result from a slight difference in the particle size of the two fillers (Table 2). The effect of modifying the filler with the coupling agent is that long polymer chains become stable in the structure of the matrix while the energy required for the initiation of polymer chain motion increases [12]. High contents of Silfit Z91, despite no applied chemical modification of particle surface, also lead to a rapid drop in the maximum strains, which can result from the accumulation of large amounts of imprecisely mixed mineral particles on the section of the specimen and low interaction between the filler particles and the polymer matrix, as well as the nature of polymer reinforcement with dispersed particles $[16,21]$.

\subsection{Impact strength}

Analyzing the results for all tested specimen batches, i.e. three types of Neuburg Siliceous Earth and all filler contents, we can observe that there occurs no single case of complete specimen fracture. Given the lack of complete fracture, it must, therefore, be stated that based on ISO 179-1:2010 the impact strength of all tested specimens is $0 \mathrm{~kJ} / \mathrm{m}^{2}$. Examples 
of specimens after the impact strength tests are shown in Fig. 6. Based on the experimental results and the behavior of the specimens during the impact test, we can, however, draw some conclusions about the strength of the tested specimens. Due to the impact, the specimens made of Silfit Z91-filled PE undergo deformation and then they fall out of the holder. Using a comparative method it has been found that the deflection angle increases with increasing the filler content. A different observation was made for the specimens containing Aktifit VM - they undergo slight deformation but do not fall out of the holder, while the drop weight rebounds. It has been estimated by a comparative method that the deflection angle of the specimens decreases after the impact with increasing the content of Aktifit VM. In the tests of Aktisil VM56-filled specimens, the drop weight also rebounds during the impact. The angle of deflection slightly increases with changing the filler content in a range between $10 \mathrm{wt} \%$ and $40 \mathrm{wt} \%$. It is however difficult to estimate the deflection at higher contents of Aktisil VM56 due to the occurrence of partial cracking. The observed phenomena confirm the previously reported relationships between rigidity and strain versus applied filler contents.

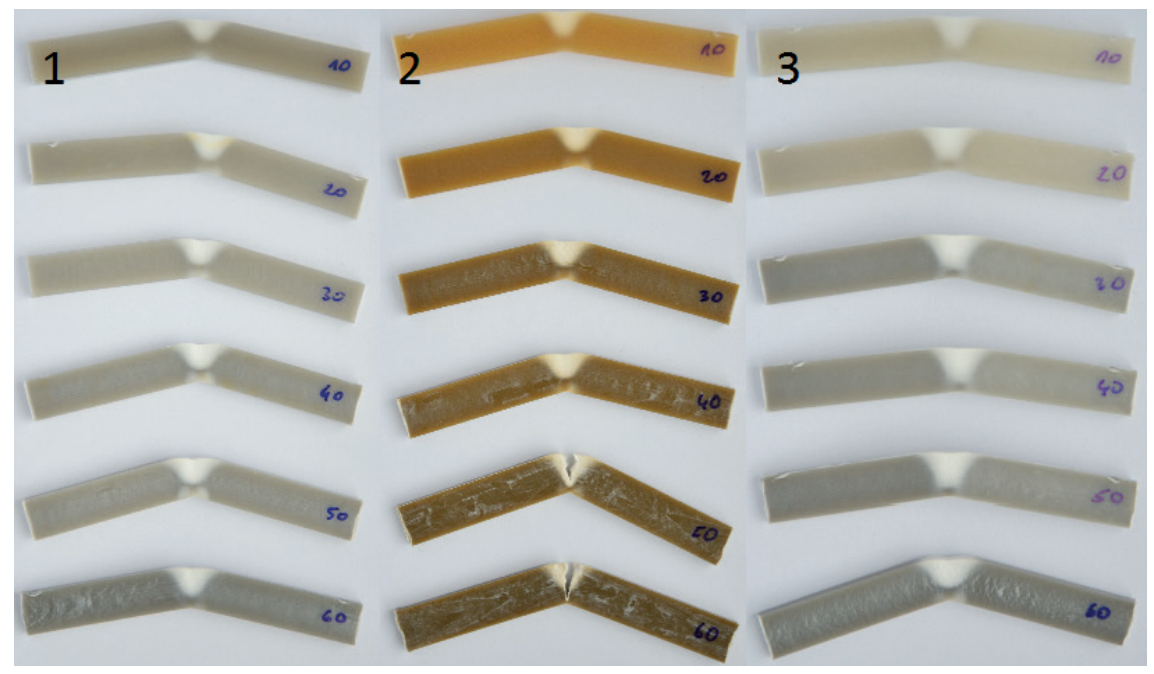

Fig. 6. Specimens after impact strength tests: 1 - Aktifit VM, 2 - Aktisil VM56, 3 - Silfit Z91

\subsection{Hardness}

The chart given in Fig. 6 illustrates the hardness of injection molded pieces versus the type and content of the filler. The results are similar for the three investigated types of Neuburg Siliceous Earth.

Initially, the hardness increases to the maximum value for $30 \%$ content of the filler; a further increase in the filler content causes a slight decrease in hardness. The measured values of the maximum harness are respectively: $66.1^{\circ} \mathrm{ShD}$ for Aktisil VM56, 66.5 $5^{\circ} \mathrm{ShD}$ for Aktifit VM and $64.7^{\circ} \mathrm{ShD}$ for Silfit Z91. The differences between the hardness of the original $\mathrm{PE}\left(60^{\circ} \mathrm{ShD}\right)$ and that of the composite with $60 \mathrm{wt} \%$ of the filler are: $10.2 \%$ for Aktisil VM56, $10.8 \%$ for Aktifit VM, and 7.8\% for Silfit Z91, respectively. 


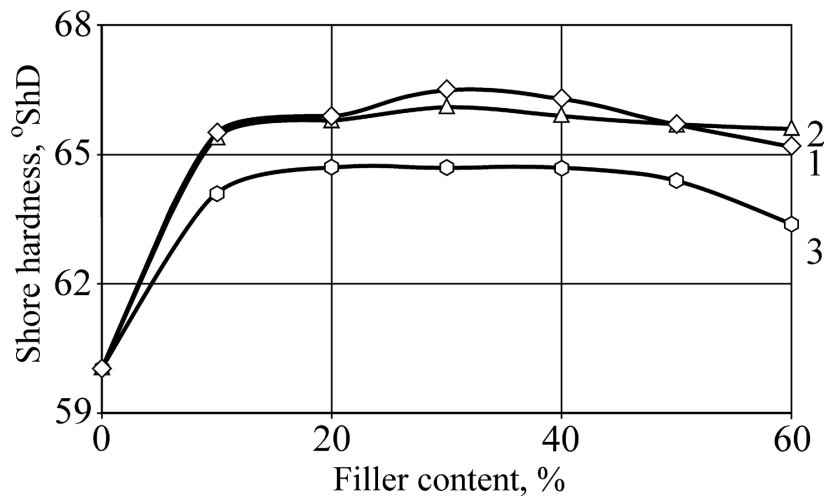

Fig. 7. Shore hardness versus filler content: 1 - Aktifit VM, 2 - Aktisil VM56, 3 - Silfit Z91

The addition of the mineral filler leads to a higher degree of crystallinity of the polymer matrix in the immediate vicinity of the filler $[4,12,16,17]$. The increase in hardness of the composites containing silane can result from the fact that the addition of silica-organic compounds causes an additional increase in the degree of crystallinity of the polymer matrix [3]. It is, however, difficult to explain the drop in hardness at the maximum filler contents based on the test results.

\section{Conclusions}

The effect of the filler on the polymer matrix depends on a number of factors, the most important of these being the size and shape of particles as well as the type of adhesive interactions. The above factors have a decisive effect on the impact between the matrix polymer and the disperse phase. The strength of the tested mineral fillers predominantly depends on their chemical properties which are, in turn, affected by modification via the addition of adhesion promoters. The highest strength has been observed for the fillers treated with vinylfunctional silanes.

Comparing the results of the composites filled with Silfit Z91 and Aktifit VM, it can be observed that the addition of the fillers containing silane-based adhesion promoters leads to higher mechanical properties of the composites than is the case with the fillers which do not contain any coupling agent. The chemical modification of the mineral fillers can lead to producing composites with the desired physical and mechanical properties at relatively low costs.

The results of the specimens filled with Silfit Z91 demonstrate that the filler has a negative influence on their strength properties which, in many cases, are lower than the properties of the original PE. In addition, the results for the composites containing Silfit Z91 significantly differ from those obtained for the specimens filled with vinyl-functional silane.

The results demonstrate that the mechanical properties of the tested composite materials can be shaped as desired via the addition of a suitable content of silane-treated NSE. Given the observed improvement in the mechanical properties of the tested NSE-filled specimens, it can be concluded that this type of filler is suitable for polyethylene injection molding. 
The authors would like to thank the German Academic Exchange Service (DAAD) and Prof. Dr. Ing. Torsten Merkel, head of the Institut für Produktionstechnik of Westsächsische Hochschule in Zwickau, for financial and organizational support of the research.

\section{References}

[1] Osswald T., Turng L., Gramann P., Injection molding handbook, Hanser Publishers, Munich 2001.

[2] Katz H., Milewski J., Handbook of fillers for plastics, Van Nostrand Reinhold, New York 1987.

[3] Rothon R., Particulate-filled polymer composites, Second Edition, Rapra Technology Limited, Shawbury 2003.

[4] Rothon R., Mineral fillers in thermoplastics, filler manufacture and characterisation, Advances in Polymer Science, 139, 1999, 67-107.

[5] Xiang B., Jiang G., Zhang J., Surface modification of TiO2 nanoparticles with silane coupling agent for nanocomposite with poly(butyl acrylate), Plastics, Rubber and Composites, 44, 2015, 148-154.

[6] Hidayah N., Mariatti M., Ismail H., Kamarol M., Evaluation of PP/EPDM nanocomposites filled with $\mathrm{SiO} 2, \mathrm{TiO} 2$ and $\mathrm{ZnO}$ nanofillers as thermoplastic elastomeric insulators, Plastics, Rubber and Composites, 44, 2015, 259-264.

[7] Samujło B., Sikora J. W., The impact of selected granulometric properties of poly(vinyl chloride) on the effectiveness of the extrusion process, Journal of Polymer Engineering, 28, 2013, 77-85.

[8] Sikora J. W., Sasimowski E., Influence of the length of the plasticating system on selected characteristics of an autothermal extrusion process, Advances in Polymer Technology, 24, 2005, 21-28.

[9] Chou T., Structure and properties of composites. Materials science and technology, Volume 13, Structure and properties of composites, VCH Verlagsgesellschaft, Weinheim 1993.

[10] Mareri P., Bastide S., Binda N., Crespy A., Mechanical behaviour of polypropylene composites containing fine mineral filler, Effect of filler surface treatment, Composite Science and Technology, 58, 1998, 747-752.

[11] Głogowska K., Sikora J. W., Duleba B., Effect of mechanical properties of metal powderfilled hybrid moulded products, Journal of Polymer Engineering, 7, 36, 2016, 705-712.

[12] Pukanszky B., Fekete E., Adhesion and surface modification, Advances in Polymer Science, 139, 1999, 109-217.

[13] Heckl S., Oggermüller H., Zehnder M., Neuburg Siliceous Earth in MS-polymer based Sealants, Hoffman Mineral GmbH, www.hoffman-mineral.com, access 15.11.2017.

[14] Göske J., Kachler W., Morphology, physicochemistry and phase analysis of Neuburg Siliceous Earth, Microscopy and Analysis, 22, 2008, 23-24.

[15] Functional fillers for coatings, Hoffman Mineral GmbH, www.hoffman-mineral.com (access 15.11.2017). 
[16] Zuiderduin W., Westzaan C., Huetink J., Gaymans R. J., Toughening of polypropylene with calcium carbonate particles, Polymer, 44, 2003, 261-275.

[17] Fu S., Feng X., Lauke B., Mai Y., Effects of particle size, particle/matrix interface adhesion and particle loading on mechanical properties of particulate-polymer composites, Composites, Part B, 39, 2008, 933-961.

[18] Tjong S., Structural and mechanical properties of polymer nanocomposites, Materials Science and Engineering, R. Reports, 53, 2006, 73-197.

[19] Liu Q. Spears D., Liu Q. MAS NMR study of surface-modified calcined kaolin, Applied Clay Science, 19, 2001, 89-94.

[20] Zuhua Z., Xiao Y., Huajun Z., Yue C., Role of water in the synthesis of calcined kaolin-based geopolymer, Applied Clay Science, 43, 2009, 218-223.

[21] Kim G., Michler G., Micromechanical deformation processes in toughened and particle filled semicrystaline polymers, Part 2, Model representation for micromechanical deformation processes, Polymer, 39, 1998, 5699-5703.

[22] Liu P., Polymer modified clay minerals, A review, Applied Clay Science, 38, 2007, 64-76.

[23] Fischer H., Polymer nanocomposites, from fundamental research to specific applications, Materials Science and Engineering C, 23, 2003, 763-772.

[24] Alexandre M., Dubois P., Polymer-layered silicate nanocomposites, preparation, properties and uses of a new class of materials, Materials Science and Engineering, 28, 2000, 1-63.

[25] Suberlyak O.V., Krasins'kyi V.V., Moravs'kyi V.V., Gerlach H., Jachowicz T., Influence of aluminosilicate filler on the physicomechanical properties of polypropylene-polycaproamide composites, Materials Science, 50, 2014, 296-302.

[26] PN-EN ISO 294-1, 2002 Tworzywa sztuczne - Wtryskiwanie kształtek do badań z tworzyw termoplastycznych - Część 1, Zasady ogólne, formowanie uniwersalnych kształtek do badań i kształtek w postaci beleczek.

[27] PN-EN ISO 527-1, 2012 Tworzywa sztuczne - Oznaczanie właściwości mechanicznych przy statycznym rozciąganiu - Część 1 , Zasady ogólne.

[28] PN-EN ISO 179-1, 2010 Tworzywa sztuczne - Oznaczanie udarności metodą Charpy'ego - Część 1, Nieinstrumentalne badanie udarności.

[29] PN-EN ISO 868, 2005, Tworzywa sztuczne i ebonit - Oznaczanie twardości metodą wciskania z zastosowaniem twardościomierza (twardość metodą Shore’a). 